\title{
Do per Capita Water Use Regulations Penalize Growing Urban Economies
}

\author{
Frederick Bloetscher, Robert J. Eustice \\ Department of Civil, Environmental and Geomatics Engineering, Florida Atlantic University, Boca Raton, FL, USA \\ Email: h2o_man@bellsouth.net
}

How to cite this paper: Bloetscher, F., \& Eustice, R. J. (2016). Do per Capita Water Use Regulations Penalize Growing Urban Economies. Current Urban Studies, 4, 376-391. http://dx.doi.org/10.4236/cus.2016.43025

Received: July 25, 2016

Accepted: September 27, 2016

Published: September 30, 2016

Copyright $\odot 2016$ by authors and Scientific Research Publishing Inc. This work is licensed under the Creative Commons Attribution International License (CC BY 4.0).

http://creativecommons.org/licenses/by/4.0/

\section{(c) (i) Open Access}

\begin{abstract}
Water has shaped nations for centuries. However as populations have expanded and economies grow, the demand for water has increased substantially. Large amounts of water are needed for agriculture, power and daily living. This water is often removed from the downstream hydrologic cycle exacerbating current water shortfalls. There are a variety of means to address water demands. However they are disproportionately placed on urban users as those users are the easiest to measure and regulate. Urban users are asked to curtail water use, convert to alternative sources and can be regulated on per capita water use. Per capital water use is often used to show where there is "wasted" water use, usually in the form of excessive irrigation. Most such communities are distinctly urban-large areas with large and diverse populations, which often include a large tourist contingent. However such a metric may penalize successful communities with diverse economic bases, thereby limiting the potential for these urban communities to grow their economies and forcing local officials into difficult decisions with respect to growth, development and job opportunities for their residents. The issue is particularly significant because urban use is only $12.6 \%$ of total water use in the United States.
\end{abstract}

\section{Keywords}

Conservation, Urban Water Use, Commercial Use, Economic Activity

\section{Introduction}

Many factors affect water use. Estimates indicate that from 1950 to 1980, demands for water increased steadily across all sectors, with 1980 being the peak water use year (Konikow, 2013). Currently, about $40 \%$ of all water is used by agriculture (Lisk et al., 2012; GAO, 2012). Power accounts for 39\% but will demand more water as the Energy Information Administration (EIA) projects an overall increase in the demand for power 
due to population increases of about 70 million in the next 25 years. Urban demands consume 12.6\% of water use (Sanders and Webber, 2012; Bloetscher and Muniz, 2012), but this demand is not evenly distributed to areas with plentiful supplies. Macknick et al. (2012) identified climate change, population growth, and demographic shifts as significant uncertainties expected to exacerbate the challenges associated with managing both the supply and demand of water. Despite these pressures, since 1980, total withdrawals have declined although the built environment demands have continued increase (Konikow, 2013). Total urban (domestic and public) withdrawals have consistently increased from 29.44 MML/s (16 bgd) in 1960 to $59 \mathrm{MML} / \mathrm{s}$ (32 bgd) in 1995 and to $79 \mathrm{MML} / \mathrm{s}$ (43 bgd) in 2005 (Solley et al., 1998; Hoffmann et al. 2005). Weather patterns and population growth into areas that are water poor (Arizona, Nevada, much of the southeast, Texas as examples) have complicated the task of meeting water demands, especially when periodic droughts and water shortages can be severe.

The concept of drought or water shortages is indicative of: 1) demands on existing sources from economic growth and population, and 2) uneven or deficient rainfall patterns-in other words, not enough rain in the right place at the right time, or too much use of the water in the wrong place at the wrong time. The result is the need to understand the new limitations in water use. One of the most expedient ways to improve the situation is water conservation. Experts have compiled large data bases on the effectiveness and cost benefits of different conservation measures (Vickers, 2001; Bloetscher, 2008; Mayer \& Deoreo, 1999). The data bases have been incorporated into computer programs where a community's physical and environmental conditions can be plugged into a computer model and a benefit/cost analysis conducted on the measures under consideration (www.conserveflorida.com). The analysis can include not only implementation costs and water savings, but also such factors as applicability, reliability, political feasibility, and acceptability to the community (www.conserveflorida.com). The analysis of costs will allow for budgeting for the duration of the plan, and for providing more flexibility in responding to changing conditions. If a drought makes the need more urgent, the utility may have to speed up implementation of the program.

Curtailed water use and conservation are common topics of conversation in areas with water supplies limitations. Water conservation should be a permanent part of good water resource management best practices. This allows utilities to maximize the supply and better manage their distribution systems efficiently. Concepts like low flow fixtures, reclaimed water use and limitations on irrigation frequency have benefits of reducing needless water use. These measures are attractive in communities where water supplies are finite, or if new water supply sources are available, they are increasingly expensive. Therefore, a reduction in demand provides a proportional reduction in future supply needs. As a result, water conservation should not be just an emergency measure as a response to a drought or temporary shortage, but it often is regulated this way. Emergency reductions bring the possibility of revenue shortfalls-southeast Florida utilities "rewarded" the highly successful efforts to reduce water use by residents with surcharges because the revenues decreased drastically as well. 
As demands for limited water resources continue to grow among all sectors, tools must be developed to prioritize and allocate water resources effectively. When creating a regulatory framework, or when trying to measure water use efficiency, water supply managers often look for easily applied metrics to determine where water use can be curtailed. Per capita water use and water use patterns have been the subject of studies going back as far as Whitman (1932). Holdren and Ehrlich (1974) outlined rising per capita material consumption, and how technologies have made civilization a global ecological force. Hall et al. (1988) looked at per capita water use in southwest England. More recently, Gleick $(1996,2003)$ and Solley et al. (1998) have looked at water uses in the United States with an eye to sustainability. Vickers (2001) completed a landmark study that broke down domestic water use into pieces and identified irrigation as a major use area that could be reduced. Solley et al. (1998) and Hoffmann et al. (2005) note that overall per capita usage dropped slightly since 1985. But in all of these studies, per capita consumption has been a focus without identifying any associated impacts.

The national average for urban community water use is 300 - 450 liters per capita per day $(\mathrm{L} / \mathrm{c} / \mathrm{d})(100-150$ gallons per capita per day (gpcd)). This national average represents residents living in metered conditions, and who are responsible for paying monthly water bills. Mayer \& Deoreo (1999) found that residential customers typically use about half of their water inside the home. The America Water Works Association estimated that this amounts to about 78 gallons per capita per day (gpcd-Mayer \& Deoreo, 1999), while Vickers (2001) puts this figure between $140-220 \mathrm{~L} / \mathrm{c} / \mathrm{d}$ (45 and 70 gpcd), with the rest for irrigation. For comparison, Meeroff and Scarlatos (2008) indicate that south Florida residential neighborhoods typically have daily demands on the order of $220-1200 \mathrm{~L} / \mathrm{c} / \mathrm{d}$ (70-380 gpcd), which include irrigation, car washing, and multiple fixtures. However, neighborhoods vary.

The regulatory framework in communities attempts require all utilities to conform to a similar per capita use pattern, but such requirements ignore the underlying economic activity. The one-size-fits-all regulatory framework is easy to apply from a regulatory standpoint, but comes with a potential price of failing to fully grasp the consequences decision-making based on such metrics. A heavy industrial area or dense downtown commercial center may indicate high apparent per capita use, but is actually the result of vibrant economic activity. Large employment centers tend to have higher per capital use than their neighbors as a result of attracting employees to downtown, which are not included in the population. Hence urban areas with significant economic activity will be punished for their success.

The goal of this project was to understand the water use patterns in communities to determine whether per capital water use is a good surrogate for determining when the potential water supplies are not managed optimally, as regulatory agencies tend to look at per capita use in this manner despite the fact that limiting water use or the lack of water supplies has long been known to impact the ability of a community to attract economic activity, but no studies of the usage patterns has been conducted. The case study was to look at utilities regulated by the South Florida Water Management District 
in an urban area (southeast Florida), where enough information existed on water use, irrigation use (or not), economic activity and unaccounted for water could be addressed. The District also regulates using per capita use as a factor.

\section{Methodology}

Data was initially collected from the South Florida water Management District on per capital water use from reports submitted annually to the District. While many utilities fit in the range from $220-800 \mathrm{~L} / \mathrm{c} / \mathrm{d}$ (70 to over $250 \mathrm{gpcd}$ ); there were drastic differences in water use per capita. For example, North Lauderdale is only $260 \mathrm{~L} / \mathrm{c} / \mathrm{d}(82 \mathrm{gpcd})$ while Fort Lauderdale is $(660 \mathrm{~L} / \mathrm{c} / \mathrm{d}$ (201 gpcd) (see Table 1). The City of Dania Beach has a $500 \mathrm{~L} / \mathrm{c} / \mathrm{d}(150 \mathrm{gpcd})$ usage, but their residential portion is under $222 \mathrm{~L} / \mathrm{c} / \mathrm{d}$ (70 gpcd). Findings in water use permits for Dania Bach in 2008 indicated both single and multi-family users used $220 \mathrm{~L} / \mathrm{c} / \mathrm{d}(70 \mathrm{gpcd})$, while the figures were $210 \mathrm{~L} / \mathrm{c} / \mathrm{d}$ (67) for single family and $190 \mathrm{~L} / \mathrm{c} / \mathrm{d}$ (58 gpcd) for multi-family users in 2012 (Bloetscher, 2014). Research conducted for Broward County utilities indicated that with the exception of Deerfield Beach and Pembroke Park, economically disadvantaged multi-family use areas with very low usage rate, and the beach which had high usage; the average water use was 6000 gallons per month, which with the average household size of 2.26 people is 89 gpcd. 89 gpcd is an acceptable number for south Florida and close to the $87 \mathrm{gpcd}$ reported in Mayer \& Deoreo (1999). The beach is an area that uses potable water for irrigation and swimming pool are noticeably higher. Miami-Dade Water and Sewer District reports an average indoor consumption of $103 \mathrm{gpcd}$ because of limited irrigation area (more urbanized) outdoor usage of 55 gpcd (Bestard, 2008). Irrigation is often identified as one of the reasons while per capita water use is higher, but that does not explain the differences in Table 1 since few of the users of these systems have irrigation users connected to the potable water system. None of these utilities has a large unaccounted for water so the figures do not indicate that any of these utilities is wasting water. As a result the scope was expanded to all utilities in Miami-Dade, Broward and Palm Beach Counties.

\subsection{Data Collection}

The methodology for collecting the copious data needed for this analysis is to translate raw data and data files into an ArcGIS format (ESRI). A geographical information sys-

Table 1. Examples of differences in per capita usage (Source: SFWMD, 2008).

\begin{tabular}{cccc}
\hline Utility & Population & ADF (MGD) & gpcd \\
\hline Margate & 60,402 & 6.77 & 112.1 \\
Broward County & 64,209 & 9.30 & 144.8 \\
N. Lauderdale & 33,167 & 2.72 & 82.0 \\
Tamarac & 55,108 & 6.25 & 113.4 \\
Ft. Lauderdale & 237,492 & 47.81 & 201.3 \\
\hline
\end{tabular}


tem (GIS) is a computer system designed to capture, store, manipulate, analyze, manage, and present all types of spatial or geographical data. The benefit of using GIS for this project is that a GIS system allows us to create data layers these layers permit a query to be performed which will allow investigators to answer specific questions. Table 2 shows the layer and the data sources. The following paragraphs discuss each of these sources in more detail.

\subsubsection{Water Use Data}

Water use data was collected from the South Florida Water Management District. Utilities that exist within South Florida Water Management District are subject to a mandatory reporting each year: the public water supplies utilities annual progress report. An underlying assumption is that all data is assumed to be correctly entered by the utility provider. The original spreadsheet provided data provided to the South Florida Water Management District provides:

- The utility names and which counties they fall into,

- the population and,

- total finished water for 2013.

In addition, a geographical information system file which contained the service area of the utilities was obtained from SFWMD.

\subsubsection{Geographical Information System Files}

The geographical information system (ArcGIS map) files used for this research where obtained from the Urban and Regional Planning Department at Florida Atlantic University for Palm Beach, Broward, and Miami-Dade County. The information stored in each county's shape file includes each city's name, and a corresponding the polygon (shape file) and that helps make up the County.

\subsubsection{Economic Data}

The 2007 United States Federal Census was used to find the economic data associated with each city at http://factfinder2.census.gov/faces/nav/jsf/pages/index.xhtml and then to download the data to Microsoft Excel $^{\oplus}$.

Table 2. Data sources.

\begin{tabular}{|c|c|c|c|c|}
\hline Description & Source & Date & File Name & $\begin{array}{l}\text { File } \\
\text { Format }\end{array}$ \\
\hline $\begin{array}{c}\text { Public Water Supply } \\
\text { Utilities Annual } \\
\text { Progress Reports }\end{array}$ & Patrick Martin, SFWMD & $2 / 27 / 2014$ & $\begin{array}{l}\text { Per_Capita_Summaries_ } \\
\text { For_FAU_Student }\end{array}$ & Xls \\
\hline $\begin{array}{l}\text { Shape File of } \\
\text { Broward County }\end{array}$ & Diana Mitsova, Ph.D. & $2 / 10 / 2014$ & Browardcities & $\operatorname{shp}$ \\
\hline $\begin{array}{c}\text { Shape File of Palm } \\
\text { Beach County }\end{array}$ & Diana Mitsova, Ph.D. & $2 / 10 / 2014$ & CITY_BNDRY & $\operatorname{shp}$ \\
\hline $\begin{array}{c}\text { Shape File of } \\
\text { Miami-Dade County }\end{array}$ & Diana Mitsova, Ph.D. & $2 / 10 / 2014$ & MUNICIPALITY_POLY & $\operatorname{shp}$ \\
\hline
\end{tabular}




\subsubsection{Combining Data}

To combine the data, open the South Florida Water Management Districts total finished water Excel spreadsheet and the fact finder spreadsheet were downloaded to ArcGIS. The categories for economic activity are:

- Manufacturing,

- Wholesale trade,

- Retail trade,

- Information,

- Real estate \& rentals,

- Professional, scientific, and technical services,

- Administrative and support and waste management and remediation services,

- Educational services,

- Health care and social assistance,

- Arts, entertainment, and recreation,

- Accommodation and food services,

- Other services (except public administration),

- Total.

The way the water service areas are laid out are in a way that some utilities provide water across multiple cities. So the way that was chosen to separate out each cities portion is to use the land use files; and identify the amount of businesses within each service area and use GIS to split these into ratios of water per city.

\subsection{Statistical Analysis}

To analyze the results from the master spreadsheet statistical analysis will be done using Excel $^{\oplus}$. Excel ${ }^{\circledR}$ was chosen for its wide acceptance among professionals in scientific scholars first for its flexibility and accuracy in performing statistical analysis.

\subsubsection{Descriptive Statistics}

Descriptive statistics were performed first on the final data from the master spreadsheet that combined data from all four sources. Before descriptive statistics can be applied to the data, it first must be modified so that there are no zeros within the data set. Any zeros left in the data set will cause some statistical test to either not run or give it incorrect outcomes. In addition PP and QQ plots were run to indicate if the data is normally distributed.

The information and manufacturing economic sectors were removed first from the master spreadsheet because of the lack of data found by the Census. The next step in cleaning up the data was to remove any utility that presented a zero in any economic sector. The justification behind this was that the utility that would be removed was not a complete picture of an ideal utility. To further explain this, this research is looking at developing an equation that could be used to predict water use on economic activity. By including utilities with zero economic activity in certain sectors it will alter the baseline equation. 


\subsubsection{Correlation Matrix}

A correlation matrix was used to test dependency among economic activity variables. This test aims to provide insight as to which variables will have the largest impact in be the best contributors in formulating an equation to predict water use based upon economic activity. $\mathrm{R}$ values gathered from this help determine which sectors are good predictors.

\subsubsection{Regression Model}

The regression model was performed in order to estimate the relationship among variables. This technique is used for modeling equations and analyzing several variables at once when the focus is on a relationship between a dependent variable and multiple independent variables. In this case the dependent variable is the total water use and the independent variables are the economic activity. Data must be evaluated to determine that the data is normally distributed allowing the use of a linear regression model. The statistical analysis was conducted with XLStat ${ }^{\oplus}$, a program that permits advanced statistical analysis of data in EXCEL $L^{\oplus}$ spreadsheets.

\section{Results}

\subsection{GIS Analysis}

The results for the water intensity per utility map created by GIS can be found in Figure 1. The economic highest intensity is located in Boca Raton, Delray, and West Palm Beach. Under the premise of solely looking at per capita use, this would be construed as an indication that the utilities had high per capita water use and that conservation efforts should be taken into consideration. However, when looking at Figure 2, which was created using GIS, one can see that the Broward and Boca Raton area received more of economic activity per utility. This is an indication that economic activity may be related to higher water use per capita.

\subsection{Descriptive Statistics}

The output from the standard descriptive statistics analysis can be seen in Table 3. Table 3 shows that the model has a standard deviation of 61, and a max range of 234 with a minimum of zero. An examination of the output files from the XLStat analysis can be seen in Figure 3 and Figure 4. From examining both the P-P and Q-Q plots, it can be inferred that the data is normally distributed.

\subsection{Correlation Matrix}

The results of the correlation matrix can be found in Table 3. The table displays $\mathrm{R}$ values, which are in indicators of how good a variable is at predicting. A conditional formatting function was applied in Excel show that any values at above 0.7 would be marked in red in Table 4. As would be expected the category food services holds the highest R-value within the correlation matrix; with the exception of the one-to-one values. It does not come with any surprise that food services would hold such a high $\mathrm{R}$ squared value, because in all aspects of cooking water would be needed at some point. 
Water Use Intensity Per Utility

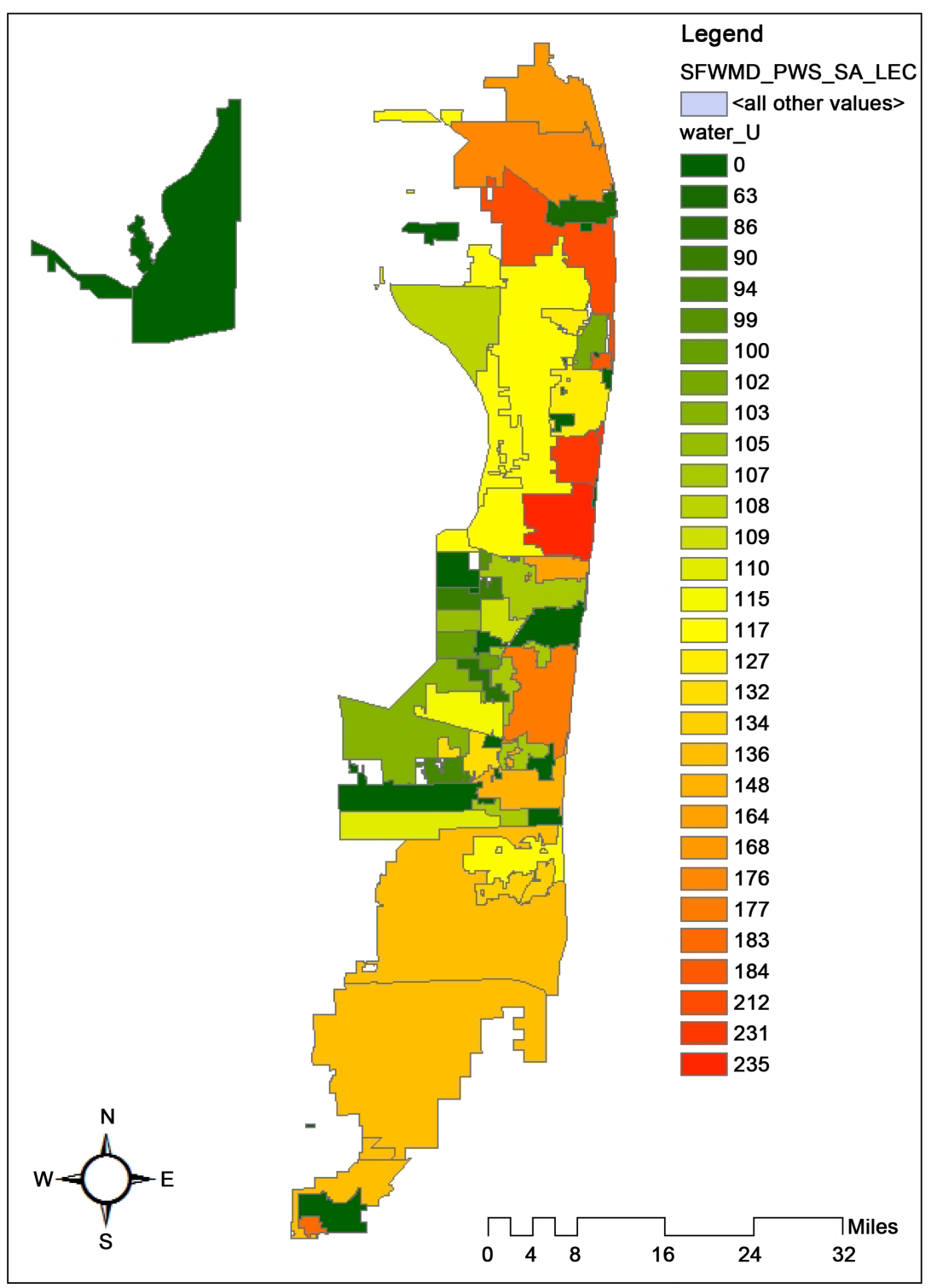

Figure 1. GIS water use intensity per utility map.

Table 3. Basic statistics.

\begin{tabular}{cc}
\hline Statistic & UNIFORM GROSS PER CAPITA 2013 \\
\hline No. of observations & 41 \\
Minimum & 0.000 \\
Maximum & 234.540 \\
1st Quartile & 96.610 \\
Median & 115.430 \\
3rd Quartile & 148.110 \\
Mean & 113.906 \\
Variance (n -1$)$ & 3729.435 \\
Standard deviation $(\mathrm{n}-1)$ & 61.069
\end{tabular}


Economic Activity Intensity Per Utility

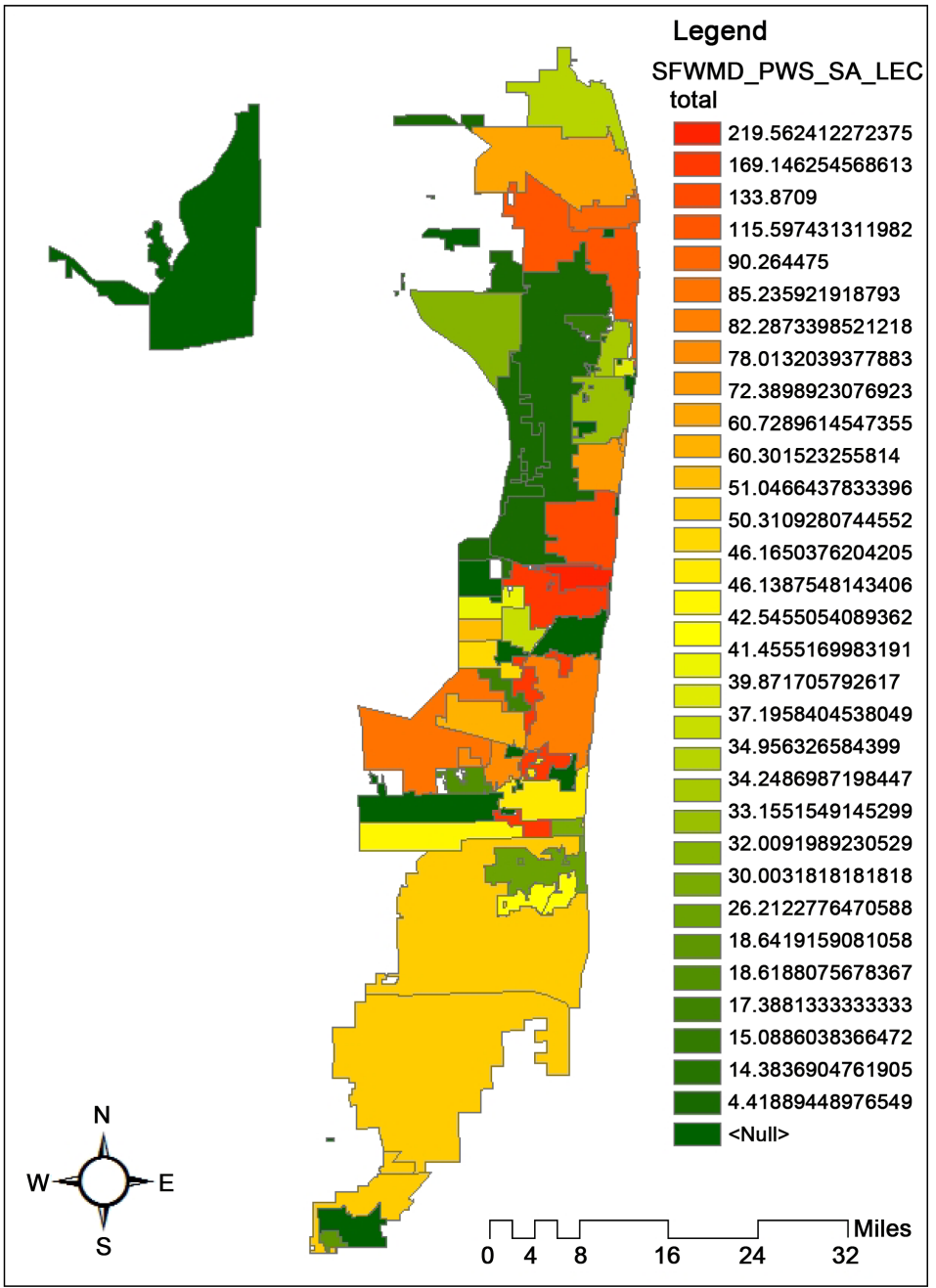

Figure 2. GIS economic activity intensity per utility.

Table 4. Correlation matrix.

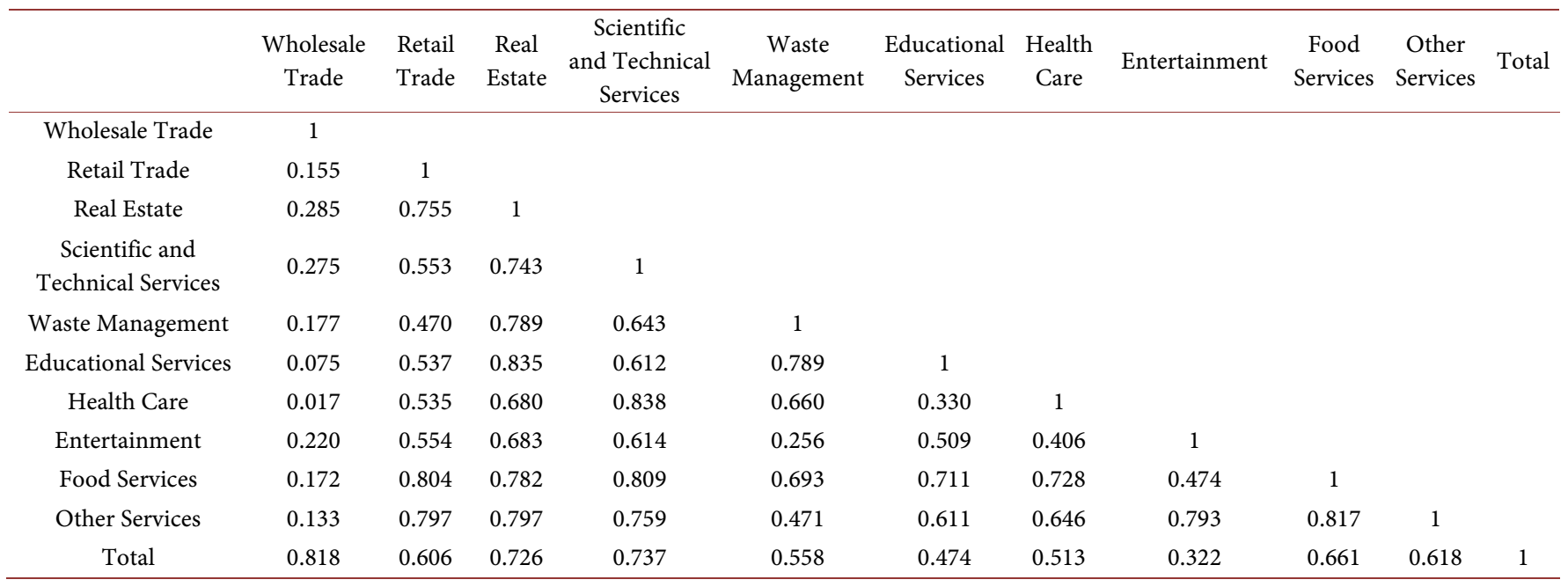




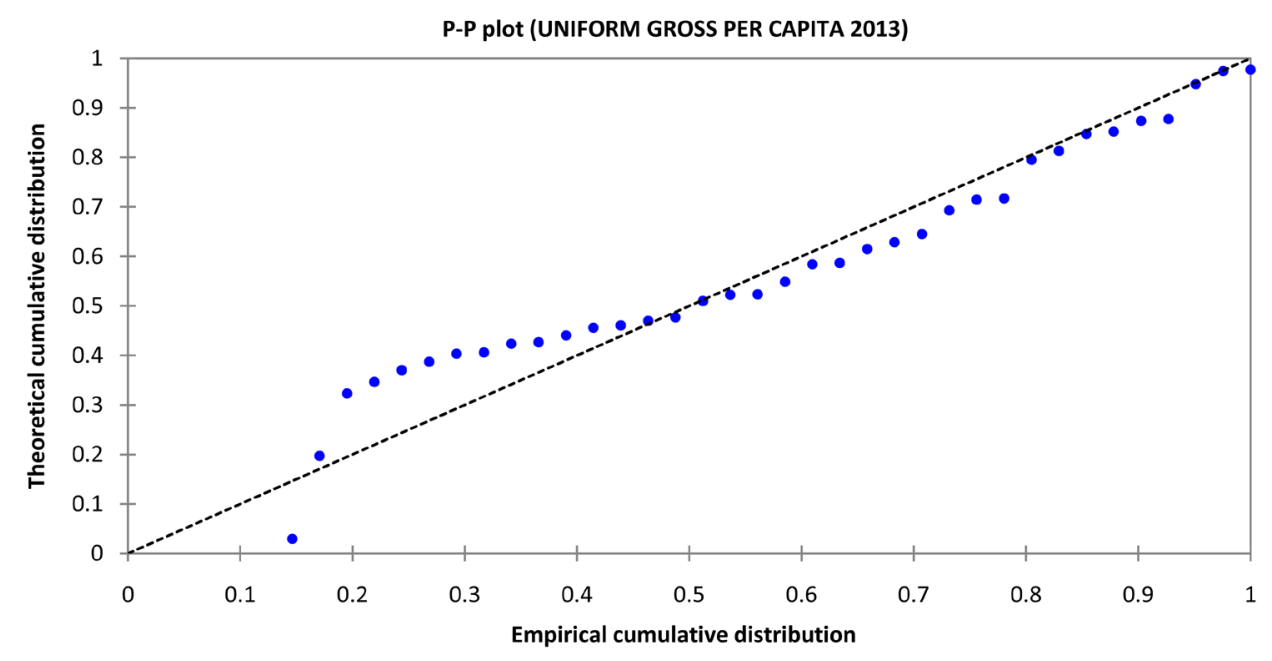

Figure 3. P-P plot.

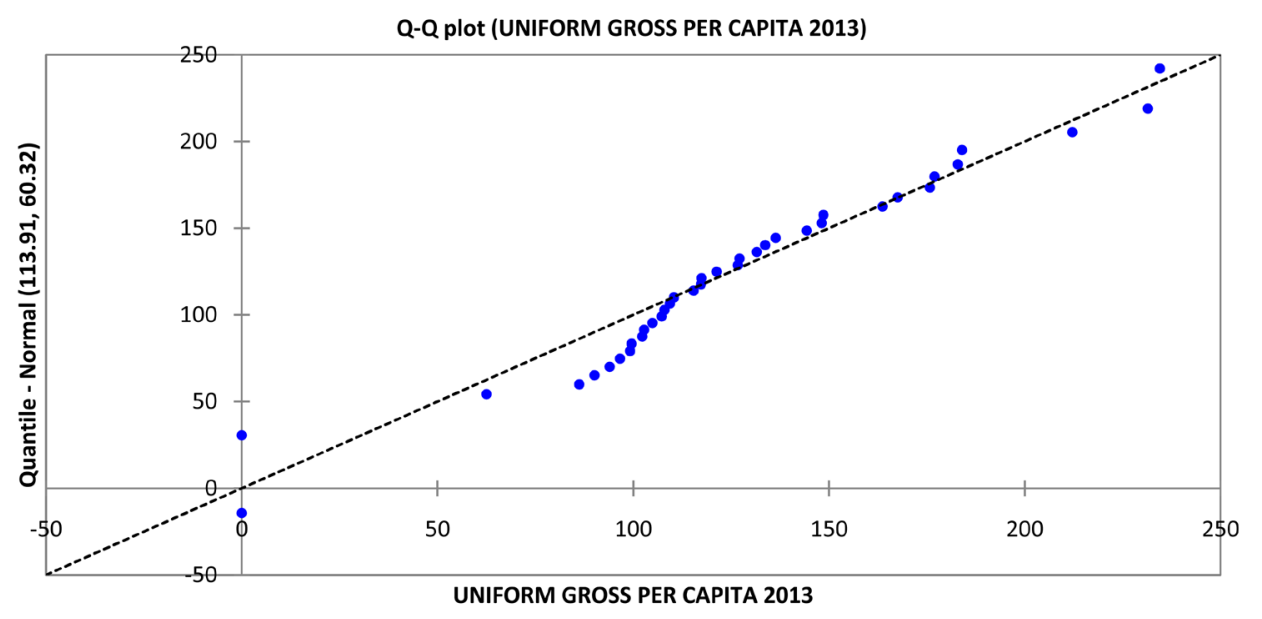

Figure 4. Q-Q plot.

On the other hand real estate has shown to be a significant contributor as well within the correlation matrix. The buying and selling of homes does not seem like something that would require high water use or correlate to any of the other economic sectors, except that in the case of south Florida, housing market drives other economic sectors.

The lowest performing economic sector within the correlation matrix is by far wholesale trade. This doesn't come as much of a surprise, because South Florida is not a large producer of wholesale goods. However South Florida is a destination or large distributors who sell retail items, and because of this the results for retail trade are somewhat disappointing. But either way, wholesale trade and retail trade are low water use economic sectors. Nothing can be definitively concluded though from these findings, and so at regression model will be needed to further analyze the results.

\subsection{Summary Plots}

Figure 5 is a summary of all economic activity by size of the utility It should be noted 


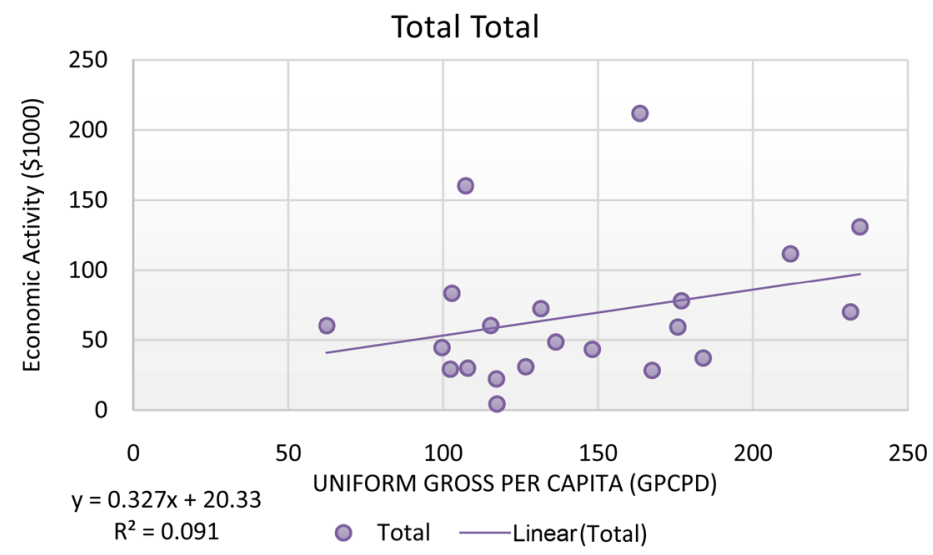

Figure 5. Total economic activity by utility.

how poorly food services R squared value was, although the trend was clearly upward. Figure 6 shows the difficulty with the overall analysis. It was postulated that food services would had a strong goodness of fit within the graph, but instead it shows that there are many outliers within the data. The preparation of food inherently uses water in all aspects. Whether it is cleaning items that will be used or the addition of potable water within the cooking itself, there was less of a relationship between economic activity and water use than expected. As can be seen in Figure 7(a), there is a very strong correlation between economic activity and water use in Palm Beach County. Broward County however as seen in Figure 7(b) has a very weak R squared value. This mean the data is not a good fit, and as a result could be the reason that the overall food services appears to not be a good indicator for water

The next graph that stood out was healthcare, which can be seen in Figure 8 . Healthcare had the highest $\mathrm{R}$ squared value among all other graphs. It was not expected at healthcare would seem like such a good indicator, but hospitals tend to be in larger communities and act as economic centers. A small community like North Lauderdale is less likely to have a hospital than Fort Lauderdale. Hence per capita would be impacted in Fort Lauderdale by health services. Likewise, a similar analysis was conducted for all sectors by county and overall (Figure 8).

\subsection{Regression Model}

Excel's regression model first output data was the statistics, which describes the fit of the data to the model. These results can be seen in Table 5 Regression Statistics. The main thing to note from the statistics is the $\mathrm{R}$ Square value. The $\mathrm{R}$ Square value tells how good of a fit the variables are with one another within the model. The value observed, 0.806 , shows that this is a good model and is a reliable prediction model. It was assumed that any P-value with a value less than 0.05 was considered statistically significant to its contribution to the model. This means that these sectors are good indicators and predictors of water use. However the values that do not meet this threshold can't be ignored; it just means that based upon the given input variables and geographical location the sectors that fail this test are not significant. 


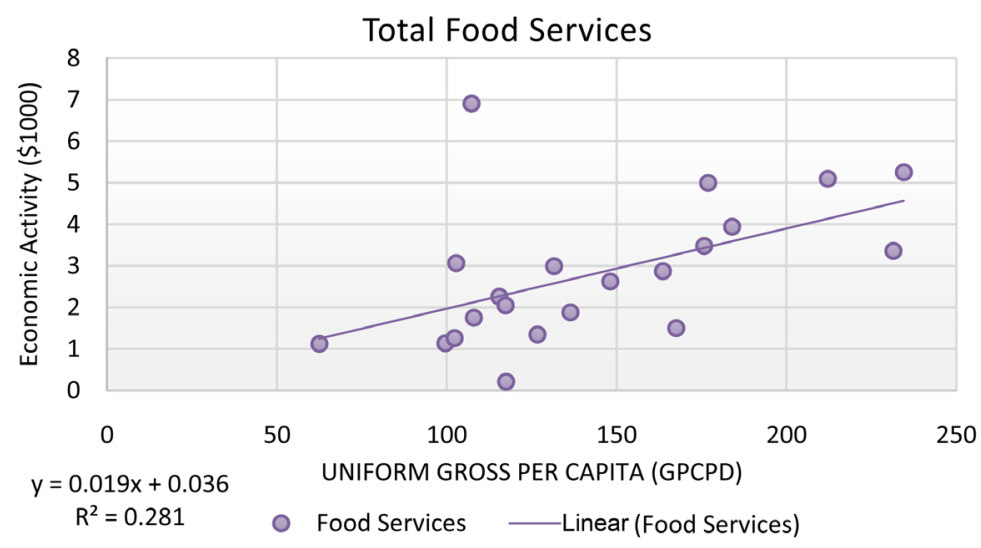

Figure 6. Total food services example (low R value) use in broward county.

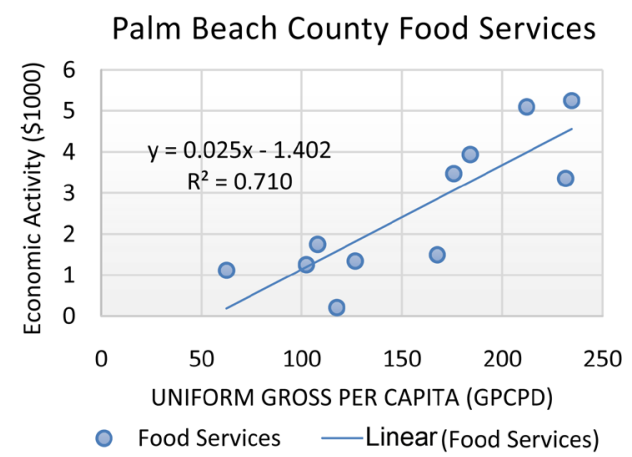

(a)

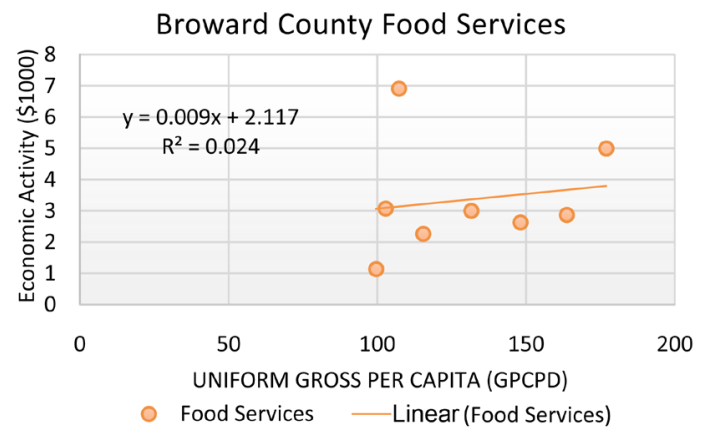

(b)

Figure 7. (a) Palm beach county food services (high R value) vs (b) Broward county food services (low $\mathrm{R}$ value-food services are more spread out).

Table 5. Regression statistics.

\begin{tabular}{cc}
\hline \multicolumn{2}{c}{ Regression Statistics } \\
\hline Multiple R & 0.898279 \\
R Square & 0.806905 \\
Adjusted R Square & 0.61381 \\
Standard Error & 28.67787 \\
Observations & 21 \\
\hline
\end{tabular}



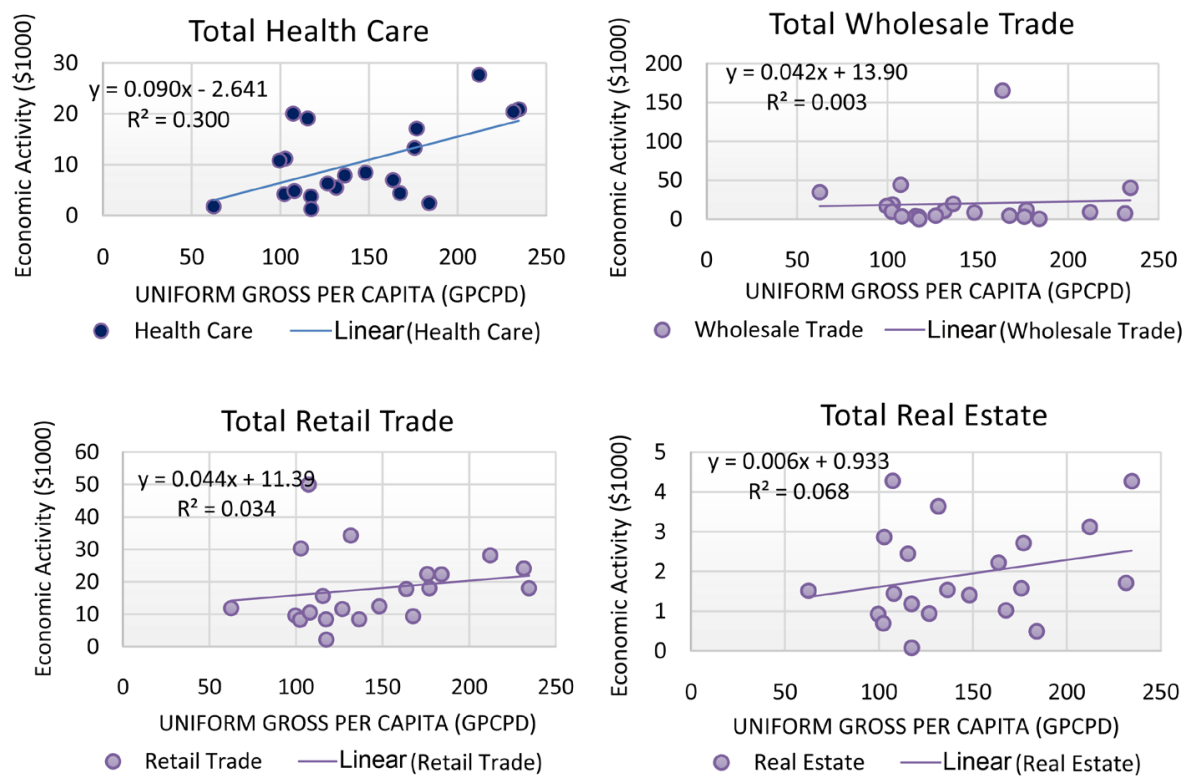

Total Scientific and Technical
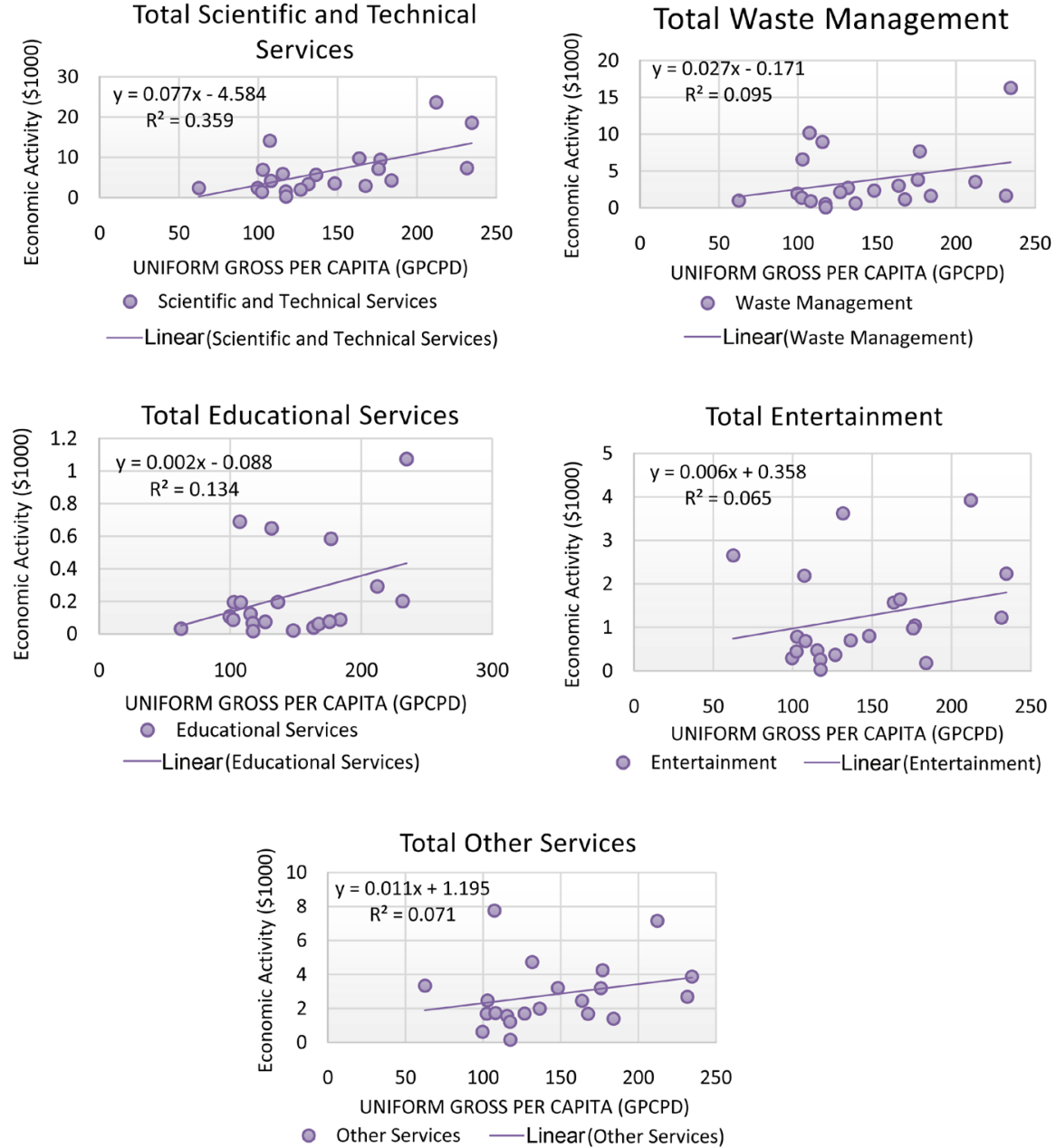

Figure 8. Summary of overall plots for all sectors of the economy-only science and technology had a high $\mathrm{R}$ Value, but all demonstrated a relationship of increasing gpcd with economic value. 
With all of the variables taken into consideration an overall prediction model was able to be created:

$$
\begin{aligned}
Y= & 101.1028+x_{1}(0.0794)+x_{2}(-1.4377)+x_{3}(-23.9936)+x_{4}(-0.5286)+x_{5}(-3.8725) \\
& +x_{6}(42.9581)+x_{7}(3.834)+x_{8}(39.3834)+x_{9}(44.7613)+x_{10}(-33.8167)
\end{aligned}
$$

where:

$x_{1}=$ Wholesale trade,

$x_{2}=$ Retail trade,

$x_{3}=$ Real estate and rental and leasing,

$x_{4}=$ Professional, scientific, and technical services,

$x_{5}=$ Administrative and support and waste management and remediation services,

$x_{6}=$ Educational services,

$x_{7}=$ Health care and social assistance,

$x_{8}=$ Arts, entertainment, and recreation,

$x_{9}=$ Accommodation and food services,

$x_{10}=$ Other services (except public administration),

$Y=$ Predicted water use in gross per capita.

As can be seen in the equation, the strongest economic indicators are Educational Services, Entertainment, and Food Services. The model was tested against the input data used in order to see how reliable the equations was. The average margin of error was $\pm 2.77 \%$, with extremes of $+52 \%$ and $-45 \%$. The results show that the equation is producing normally distributed data, but because of the small sample size it's not a smooth continuous curve.

Miami-Dade County is a cultural mix that attracts millions of people to its cities every year. What is so unique about Miami-Dade County from a water resource point of view is that there are only a few utilities that serve the entire County. After the data has been cleaned up which was covered in the methodology section, there are only two utilities that did not have zeros in their economic sectors. This results in Miami-Dade County no longer being able to produce any meaningful graphs from its data set. Because there are only two utilities all economic sectors have an $\mathrm{R}$ squared value of one indicating a perfect relationship because there are only two point's data. Miami-Dade County's data however can still be used only when it is combined with the other utilities.

\section{Conclusion}

The concept of limited water sources has two root causes: 1) demands on existing sources from economic growth and population, and 2) uneven or deficient rainfall patterns. Much literature exists about the latter, but the impact of economic growth on water demands has had limited study except at the macro level as noted previously. Limiting water use or the lack of water supplies has long been known to impact the ability of a community to attract economic activity, but no studies of the usage patterns has been conducted. To resolve the issue with varied water use, it is useful to know how per capita water use discretized. 
In this project, the intent was to look at how per capita water use and economic activity might be impacted. A series of similarly situated water utilities and their per capital usage was compared to their commercial activities to determine which activities might exert the biggest impact and develop a better metric that consider the economic development activities of the region and water use. What was found was that while there was significant variability among utilities, but the general trend of increased economic activity was related to increased per capita usage, although it was difficult to predict specific sectors. Among the significant sectors that drive water use were health care, retail trade, food service and scientific and technical services. Developing a regression equation was beneficial if predicting results for all utilities (usually within 3\%). As a result when evaluating the efficiency of a utility, an analysis should be conducted on the economic sectors to insure that water regulations do not stifle economic growth and jobs in a community.

\section{Acknowledgements}

Patrick Martin, SFWMD, Diana Mitsova, FAU.

\section{References}

Bestard, A. (2008). Let the Change Begin. Market Transformation through Incentive Programs. Water Smart Innovations Conference and Exposition, Las Vegas.

Bloetscher, F., \& Muniz, A. (2012). Where Is the Power to Treat all the Water? Potential Utility Driven Solutions to the Coming Power-Water Conflict. Florida Water Resource Journal, 64, 32-46.

Gleick, P. H. (1996). Basic Water Requirements for Human Activities: Meeting Basic Needs. Water International, 21, 83-92. http://dx.doi.org/10.1080/02508069608686494

Gleick, P. H. (2003). Water Use. Annual Review of Environment and Resources, 28, 275-314.

Hall, M. J., \& Hooper, B. D. (1988). Domesticper Capita Water Consumption in South West England. Water and Environment Journal, 2, 626-631.

Hoffmann, J., Feeley, T., \& Carney, B. (2005). U.S. Department of Energy/National Energy Technology Laboratory, DOE/NETL's Power Plant Water Management R\&D Program-Responding to Emerging Issues. 8th Electric Utilities Environmental Conference, EUEC, Tucson, 24-26 January 2005.

Holdren, J. P., \& Ehrlich, P. R. (1974). Human Population and the Global Environment: Population Growth, Rising per Capita Material Consumption, and Disruptive Technologies Have Made Civilization a Global Ecological Force. American Scientist, 62, 282-292.

Konikow, L. F. (2013). Groundwater Depletion in the United States (1900-2008): U.S. Geological Survey Scientific Investigations Report 2013-5079. 63 p. http://pubs.usgs.gov/sir/2013/5079

Lisk, B., Greenberg, E., \& Bloetscher, F. (2012). Implementing Renewable Energy at Water Utilities Web Report \#4424. Denver, CO: Water Research Foundation.

Macknick, J., Newmark, R., Heath, G., \& Hallett, K. C. (2012). Operational Water Consumption and Withdrawal Factors for Electricity Generating Technologies: A Review of Existing Literature. Environmental Research Letters, 7. http://dx.doi.org/10.1088/1748-9326/7/4/045802

Mayer, P. W., \& Deoreo, W. B. (1999). Residential End Uses of Water. Denver, CO: AWWARF.

Meeroff, D. M., \& Scarlatos, P. D. (2008). Green Lodging Project Phase 4: Green Lodging Per- 
formance Measures: Implementation and Monitoring-Progress Report: Action Plan Implementation Update. Boca Raton, FL: Florida Atlantic University.

Sanders, K. T., \& Webber, M. E. (2012). Evaluating the Energy Consumed for Water Use in the United States. Environmental Research Letters, 7, 034034.

SFWMD (2008). http://spatial.sfwmd.gov/losac/sfwmd.asp

Solley, W. B., Pierce, R. R., \& Perlman, H. A. (1998). Estimated Use of Water in the United States in 1995. Washington DC: United States Geological Survey.

Vickers, A. (2001). Handbook of Water Use and Conservation. Amhurst, MA: Water Plow Press.

Whitman, E. R. (1932). Per Capita Water Consumption. Journal American Water Work Association, 24, 515-528.

Submit or recommend next manuscript to SCIRP and we will provide best service for you:

Accepting pre-submission inquiries through Email, Facebook, LinkedIn, Twitter, etc. A wide selection of journals (inclusive of 9 subjects, more than 200 journals)

Providing 24-hour high-quality service

User-friendly online submission system

Fair and swift peer-review system

Efficient typesetting and proofreading procedure

Display of the result of downloads and visits, as well as the number of cited articles

Maximum dissemination of your research work

Submit your manuscript at: http://papersubmission.scirp.org/

Or contact cus@scirp.org 